\title{
EFL Students' Learning Style in English as General Course at Universitas Negeri Padang
}

\author{
Aryuliva Adnan and Leni Marlina \\ English Department \\ Universitas Negeri Padang \\ aryuliva.adnan@yahoo.co.id
}

\begin{abstract}
Higher education institutions attempt to improve the predicament of high failure and dropout rates by improving the quality of teaching and learning. Awareness of learning styles could help students understand how they learn and empower them to take ownership of their learning so that they persevere and succeed in the institutions of higher education. The purpose of this study is to identify learning styles prefered by students Asian EFL college students, particularly students who have studied English as General Course at Universitas Negeri Padang (UNP), West Sumatra, Indonesia. The researcher used nine categories of Mkonto's learning styles [1] which consist of Auditory Language, Visual Language, Auditory Numerical, Visual Numerical, Kinaesthetic Tactile, Social Individual, Social Group, Expressive Oral, dan Expressive Written. By using random sampling, the samples of this research were 48 students who studied English as General Course at UNP in 2016. Data was collected through a questionere. The result of this research shows that the students of English as General Course at UNP have multiple major learning styles which are dominanated by Visual Language, Kinesthetic-Tactile, and Visual Numerical. The study also shows that the most dominant major learning style owned by the students in General English Course 2016 at Universitas Negeri Padang is Visual Language. Meanwhile the most dominant learning style not owned by the students is Auditory Numerical.
\end{abstract}

Keywords-learning style, EFL college students, English course

\section{INTRODUCTION}

Experts assert that individuals enjoy various learning styles. Learning styles make an important component in the learning environment. Students differ from each other in the way they learn as each student has his or her own strength and unique intelligence, and where possible individual needs should be taken into account in the teaching process. It is important to study learning styles because recent studies have shown that a match between teaching and learning styles helps to motivate students process of learning. Language learning styles are among the main factors that help determine how - and how well - students learn a foreign or second language. A foreign language is a language studied in an environment where it is not the primary vehicle for daily interaction and where input in that language is restricted.
In Indonesia, English as a foreign language is not only studied by students at English study program, but it is also studied by other students from different departments or other study programs. To ilustrate, at Universitas Negeri Padang (UNP), State University of Padang, English is not only run by English Study Programs, but it is also run directly by University under General Course programs, Mata Kuliah Umum, (known as MKU). UNP provided English as General Course known for 3 SKS (semester credit system) some years ago. Nowadays it becomes 2 SKS. Besides, having English as General Course, UNP also run English for specific purposes for a compulsory subject for their students in each Faculty. It means that English course learned for two credit hours are not sufficient. By adding 2 SKS from course of English for Specific Purpose (English Profeciancy) at it is expected the students to be able to understand English text books.

To measure the students' ability in understanding English, UNP still uses TOEFL as it is a standardized test and it is done by UNP's language center. In UNP's regulation it is clearly stated that every student should take TOEFL as the prerequisite for having final examination (comprehension examination), for they have to submit their TOEFL score before having examination. All students are required to pass the General English subject and pass TOEFL (Test of English as Foreign Language) with certain standardized minimal score before they graduate from UNP. The facts showed that most of them took the test several time to get the score needed. This means that the students' ability in understanding English, particularly in the form of TOEFL materials is low. Based on the preliminary research done to the students at UNP, it is known that the primary problems the students have in learning English and taking TOEFL are lack of English practice and lack of vocabularies. Other problems are related to low study motivation in English and mismatch between students' learning style and teaching strategies in English as General Course classroom.

Lack of students motivation in learning English as General Course at UNP is likely caused by lack of teachers' effort in considering the varieties of students' learning styles. This is in line with what Hargove and Poteet said that one of the most neglected aspects of diagnostic activity with students is the 
determination of their unique learning style [2]. It means that the aspect of students' learning styles is one of the aspects that most neglected to be considered in teaching and learning process, meanwhile it is very important.

The optimum learning achievement will be gained when the various differences students like habit, interest, learning style are accommodated by lecturer in choosing methods, materials, which appropriate with students' learning style. The quality of teaching and learning process at University can be improved when the lecturer understand and consider the characteristics and learning of the students in choosing methods, techniques of teaching, teaching materials which are suitable with the varieties of students learning styles. When the students learning styles are suitable with the teachers' teaching styles, there will be more positive things can be gained, such as enjoyable learning atmosphere, students' motivation and interest are increased. However if the teachers' teaching styles and the students' learning styles do not match each other, it will cause disappointment and frustration for both sides.

The study of students learning styles have been popular since many years ago. Moreover, the study of language learning styles have also been popular recently. To illustrate, Karabuga has conducted a research about the relationship between EFL student's learning style and EFL teaching strategies [3]. Gilakjani has conducted a research on the learning styles of EFL college students who studied English Language Translation in Islamic Azad University of Lahijan, Iran [4]. The finding of this study revealed that the prevalent learning style among EFL students in Iran was visual one and students with this type of learning style had the greatest academic achievement in their educational major [4]. In addition, Abidin et.al have conducted a research on the learning styles of the Muslim students studying in an Islamic school in northern Malaysia [5]. The result of the study done by Abidin et. all shows that most students at Islamic school in northern Malaysia possessed multiple learning styles or a combination of different learning styles.

The study on learning styles is still very much under researched at Universitas Negeri Padang, Indonesia. Although learning styles has not received full consideration in the local educational context at Universitas Negeri Padang, it is certainly the time that learning styles be fully incorporated into the teaching services. However, without proper research in this area, it is difficult to illustrate the contribution and positive intervention of learning styles with students' overall academic achievements. Bearing the importance of learning styles in the process of language learning, the aim of this is to describe the learning styles of EFL students who were registered in English as General Course at Universitas Negeri Padang, Indonesia. The result of this research is beneficial as a consideration for lecturers who teach English as General Course, especially in choosing method and technique of teaching, and teaching materials which are suitable with EFL college students' needs and learning styles.

\section{LEARNING STYLE}

Learning styles have been defined in multiple ways, depending upon one's perspective. Learning style has been defined by various scholars mostly as a signal for individual differences. These differences may manifest itself in 'life styles' and even in personality types [6]. Learning style is an approach used by the students in learning a new language or other subjects. Similar to Oxford, Dörnyei define learning styles as "a profile of the individual's approach to learning, a blueprint of the habitual or preferred way the individual perceives, interacts with and responds to the learning environment" [7]. Learning style is sometimes defined as the characteristic cognitive, affective, social, and physiological behaviors that serve as relatively stable indicators of how learners perceive, interact with, and respond to the learning environment [8]. In addition, learning styles can be the manner in which a learner perceives, interacts with, and responds to the learning environment [9]. Furthermore, learning styles are defined by Dörnyei as "a profile of the individual's approach to learning, a blueprint of the habitual or preferred way the individual perceives, interacts with and responds to the learning environment" [7]. In addition, learning style preference is one aspect of learning style, and refers to the choice of one learning situation or condition over another [10]. The students will learn more and will enjoy the class experience and environment when they can use their preferred learning styles [4].

Some terms related to learning styles have been documented. Witkin uses field-independent and fielddependent [11]. Kolb proposes convergers, divergers, assimilators, dan accommodators [12]. Gregorc uses concrete sequential, abstract sequential, abstract random, and concrete random [13]. Willing classifies standard for classifying students' learning styles in into four parts [14]. They are concrete, analytical, authority-oriented, and communicative.

Based on personality types, Oxford classifies learning style into two groups: extrovert and introvert [15]. The learners with extrovert learning style like to interact more with others to get knowledge. They like to ask others if they do not know about something. Meanwhile the learners with introvert learning style like to analyse and work by themselves. They become introvert to interact with other persons. The extrovert and introvert learning style has some advantages. The language learners with extrovert learning style will succeed faster in learning spoken communication. The learners with the introvert learning style will succeed faster in learning reading and vocabularies.

Based on desired degree of generality, Oxford classify the learners into global and analytic [15]. The learners with global learning style prefer to learn communicative activities, while the learners with analytic prefer to learn the language structure. Seeing from 
biological differences, the enjoyment of students in learning is classified into time, place, and attitude while learning. Related to time, some learners prefer to study in the morning, at noon and in the evening. Related to place, some learners prefer to study in the classroom and outside the classroom. Related to attitude while learning some students like to have snack and some others like to listen to music while learning.

Mkonto clasifies students learning styles into nine categories. They are Auditory Language; Visual Language, Auditory Numerical, Visual Numerical, Kinesthetic tactile; Social Individu; Expressive Oral; Expressive Written [1].

TABLE 1 MKONTO'S CLASSIFICATION OF LEARNING STYLE

\begin{tabular}{|l|l|}
\hline \multicolumn{1}{|c|}{$\begin{array}{c}\text { Mkonto's } \\
\text { Learnification of }\end{array}$} & \multicolumn{1}{c|}{ Explanation } \\
\hline Auditory Language & $\begin{array}{l}\text { These students learn best from hearing } \\
\text { information presented to them. }\end{array}$ \\
\hline $\begin{array}{l}\text { Visual } \\
\text { Language }\end{array}$ & $\begin{array}{l}\text { These students learn best seeing the } \\
\text { information presented to them. }\end{array}$ \\
\hline Auditory Numerical & $\begin{array}{l}\text { These students learn best from hearing } \\
\text { numbers. }\end{array}$ \\
\hline $\begin{array}{l}\text { Visual } \\
\text { Numerical }\end{array}$ & These students learn best by seeing numbers. \\
\hline Kinaesthetic Tactile & These students learn best by being involved. \\
\hline $\begin{array}{l}\text { Social } \\
\text { Individual }\end{array}$ & These students like to study alone. \\
\hline $\begin{array}{l}\text { Social } \\
\text { Group }\end{array}$ & These students learn best when in a group. \\
\hline $\begin{array}{l}\text { Expressive } \\
\text { Oral }\end{array}$ & $\begin{array}{l}\text { These students learn best when they can } \\
\text { express themselves orally. }\end{array}$ \\
\hline $\begin{array}{l}\text { Expressive } \\
\text { Written }\end{array}$ & $\begin{array}{l}\text { These students learn best when they express } \\
\text { themselves in written form. }\end{array}$ \\
\hline
\end{tabular}

\section{METHODOLOGY}

The design of this research is basic research or academic research which aims to understand a problem that focus on theoretical benefit not on practical benefit. Besides this research also used descriptive qualitative because it described the real condition in presenting the data and analysed it to find the solution based on the research questions. The population of the research were all students registered in English as General Course in the semester of June-December 2016 at Universitas Negeri Padang. The total population consisted 33 groups and the sample was taken by using random sampling technique. The chosen group as sample was the group with the course code NA 304 which consisted of 48 students. The data was collected by distributing a questionnaire.

\section{FINDING}

The result of this research shows that the majority of students who studied English as General Course at Universitas Negeri Padang have multiple learning styles or a combination of different learning styles. Most educational psychologists would agree that multiple learning styles can significantly enhance academic achievement [16]. Tulbure supports the idea that students with different learning styles achieve better learning outcomes when onfronted with teaching strategies that respond to their learning preferences [17].

\section{The Students' Learning Style at English General Course Class}

Fig. 1. The Students' Major Learning Style in English as General Course Class 2016 at Universitas Negeri Padang

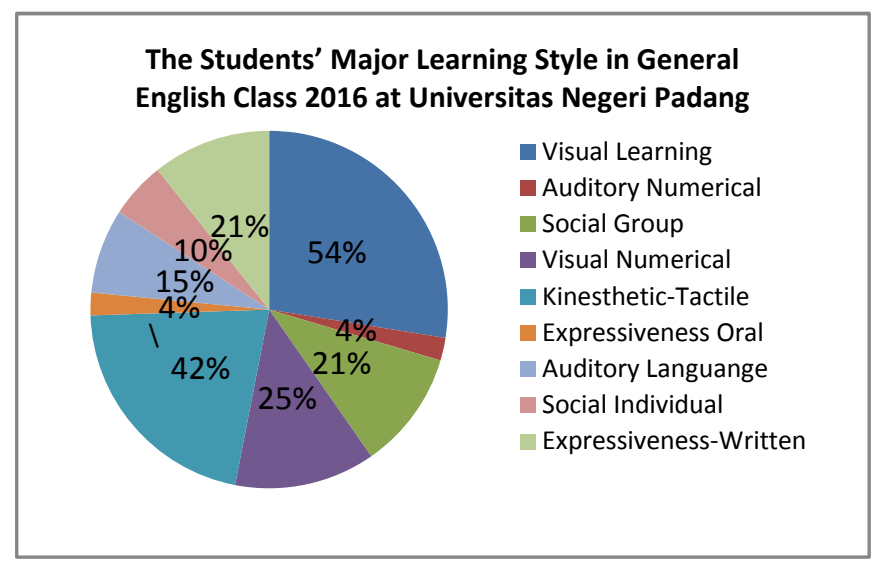

The pie chart above shows that there are 3 dominant major learning styles owned by participant students at class of English as General Course 2016 at Universitas Negeri Padang. The dominant major learning styles are Visual Language learning style with Percentage of 54\%; Kinesthetic-Tactile with Percentage of $42 \%$; and Visual Numerical with Percentage of $25 \%$. From the data contained in the pie chart above, there is a percentage of the number of student participants who have other major learning styles that are significantly smaller than the 3 dominant learning styles, such as Social Group and Expressiveness Written which have the same percentage of student numbers that is $21 \%$; Auditory Language has a percentage of $15 \%$; Social Individual has a percentage of $10 \%$; Auditory Numerical and Expressiveness Written which has the same percentage of student participants $4 \%$. So, it can be concluded that the most dominant learning style that is owned by student participants at class of English as General Course 2016 at Universitas Negeri Padang is Visual Language.

Fig 2. The Students' Minor Learning Style in English as General Course Class 2016 at Universitas Negeri Padang

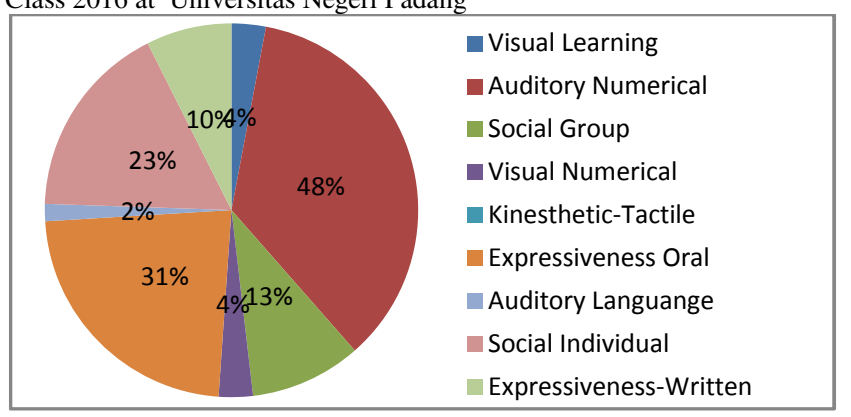

The pie chart above shows that there are 3 dominant minor learning styles that are owned by the participant students in 
General English class 2016 at Universitas Negeri Padang. The dominant minor learning styles are Auditory Numerical with Percentage of 48\%; Oral Expressiveness with Percentage of $31 \%$; and Social Individual with the percentage of $23 \%$. The pie chart above also shows a number of student participants who have other minor learning styles that are significantly smaller than 3 dominant learning styles. They are Social Group learning style with percentage of 13\%; Expressiveness Written with percentage of $10 \%$; Visual Language and Visual Numerical with percentage of $4 \%$; Auditory Language with percentage of $2 \%$. Meanwhile there is no any student who engage with Kinesthetic-Tactile learning style. So, it can be concluded that the most dominant minor learning style that is owned by student participants in General English Class Universitas Negeri Padang is Auditory Numerical.

Fig. 3. Bar chart Comparison Percentage Number of UNP Students Who Have Style Learning in English as General Course Class 2016 at Universitas Negeri Padang

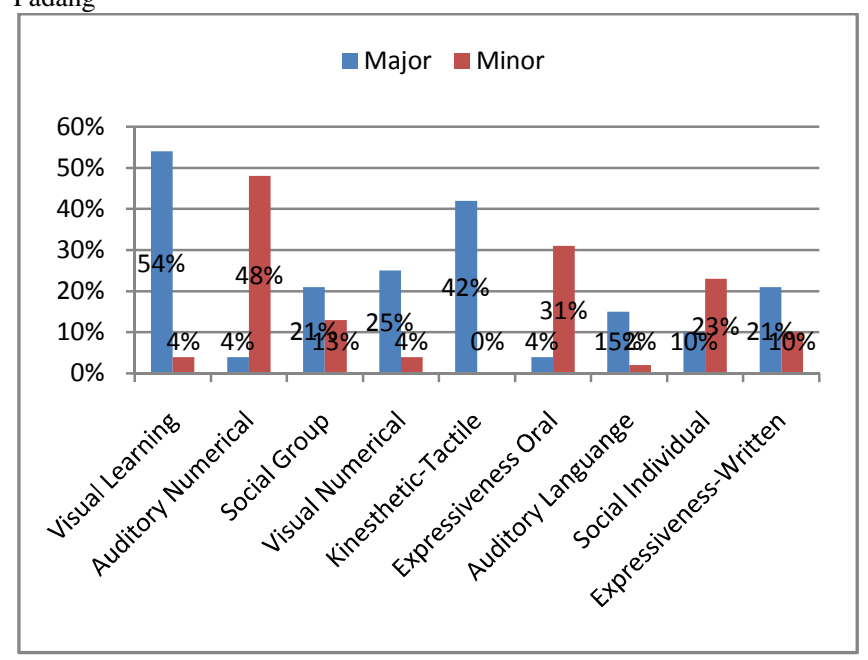

The bar chart above shows a comparison of percentage of participating students with some major learning styles and minor learning styles in English as General Course class. To make it more specific, only 3 major learning styles and 3 minor learning styles will be outlined in the paragraph below.

Comparison of percentage of student participants who have 3 dominant major learning styles can be described as follows. The dominant major learning style is Visual Language. In this learning style, student participants who have this learning style has a percentage of $54 \%$, while the percentage of students who do not have this learning style is only $4 \%$. Thus, the magnitude of the comparison between the percentage of student participants who have and do not have Visual Language learning style is significant.

Meanwhile, the dominant major learning style of the latter is Kinesthetic-Tactile. In the Kinesthetic-Tactile learning style, student participants who have this learning style have a percentage of $42 \%$, and the percentage of students who do not have this learning style is $0 \%$. So it can be said that there are no students who do not have the Kinesthetic-Tactile language style. Thus, the magnitude of the comparison between the percentage of student participants who have and did not have the Kinesthetic-Tactile learning style is significant.

The third dominant learning style is Visual Numerical. In Visual Numerical learning style, student participants who have this learning style have a percentage of $25 \%$, and the percentage of students who do not have this learning style is $4 \%$. Thus, the magnitude of the comparison between the percentage of student participants who have and do not have Visual Numerical learning style is significant.

Furthermore, comparison of percentage of student participants who have 3 dominant minor learning styles can be described as follows. The first dominant learning style is Auditory Numerical. In the learning style of Auditory Numerical, student participants who do not have this learning style have a percentage of $48 \%$, while the percentage of students who have this learning style is $4 \%$. Thus, the magnitude of the comparison between the percentage of student participants who do not have and learning style Auditory Numerical significant.

Furthermore, the second dominant minor learning style is Oral Expressiveness. In Oral Expressiveness learning style, student participants who do not have this learning style have a percentage of $31 \%$, and the percentage of students with this learning style is $4 \%$. Thus, the magnitude of the comparison between the percentage of student participants who do not have and Oral Expressiveness learning style is significant.

The third dominant minor learning style is Social Individual. In the Individual learning style, students who do not have this style of learning have a percentage of $23 \%$, and the percentage of students with this learning style is $10 \%$. Thus, the magnitude of the comparison between the percentage of student participants who do not have and the learning style of Social Individual is not much different.

From the comparison percentage explanation about the learning style of MKU students in English above, can be known three important things about the student's major learning style. First, the magnitude of the comparison between the percentage of student participants who have and do not have Visual Language learning style is significant. Secondly, the magnitude of comparison between percentage of student participants who have and does not have Kinesthetic-Tactile learning style is very significant. Third, the magnitude of comparison between percentage of student participants who have and do not have Visual Numerical learning style is significant. Thus it is clear that the students of MKU English UNP Padang have a major learning style dominated by the style of Visual Language, Kinesthetic-Tactile, and Visual Numerical.

Furthermore, from the comparison percentage explanation about the learning style of MKU students in English above, can be known three important things about the student's minor learning style. First, the magnitude of the comparison between the number of student participants who do not have and learning style Auditory Numerical significant. Second, the magnitude of the comparison between the number of student participants who do not have and Oral Expressiveness learning style is significant. Third, the magnitude of the comparison 
between the number of student participants who do not have and have a different style of Social Individual learning. Thus it is clear that the students of MKU English UNP Padang have a minor learning style dominated by Auditory Numerical, Oral Expressiveness, and Social Individual.

\section{DISCUSSION}

Learning styles are not dichotomous (black or white, present or absent). Learning styles generally operate on a continuum or on multiple, intersecting continua. For example, a person might be more extraverted than introverted, or more closure-oriented than open, or equally visual and auditory but with lesser kinesthetic and tactile involvement. Furthermore, learning styles affect learners' learning behaviours [5]. Learners having different learning style preferences would behave differently in the way they perceive, interact, and respond to the learning environment.

Sabeh et al. suggests that respecting others' styles and responding to different styles by accommodating some strategies could help promote learning [18]. The more that teachers know about their students' style preferences, the more effectively they can orient their teaching instruction, as well as the strategy teaching that can be interwoven into language instruction, matched to those style preferences. Some learners might need instruction presented more visually, while others might require more auditory, kinesthetic, or tactile types of instruction. Without adequate knowledge about their individual students' style preferences, teachers cannot systematically provide the needed instructional variety.

Students who have visual styles as dominant learning styles will learn more effectively by getting the following learning materials: (1) images, colors, maps, videos, posters, slides; (2) frame of mind; (3) underscores, notes; (4) textbooks with diagrams, illustrations and drawings; (5) body language / facial expressions of the teacher; (6) marking important parts with different colors; (7) visual symbols.

Students who have visual styles as dominant learning styles will be more successful in understanding learning materials in the following ways: (1) Using all the above learning materials; (2) Use color markers to mark important things; (3) Reconstruct images in different ways such as creating different spatial arrangements; (4) Redrawing pages from memory; (5) Replace words with symbols or initials; (6) Viewing pages; (7) Illustrates the existing ideas into the picture.

Students who have a visual style as dominant learning style will want the following: (1) An overview so they can be more holistic than reductionist; (2) They are often affected by the look of the object; (3) They are interested in color, layout, and design; (4) They may draw something; (5) Expect a demonstration or practice rather than an oral explanation.

Students who have auditory numerical as a dominant minor learning style will learn more effectively by obtaining learning materials as follows: (1) Books, (2) Recording devices, (3) Music, (4) Materials taught with Verbal discussion.
Students who have auditory numerical as a dominant minor learning style will be more successful in understanding the learning materials in the following ways: (1) Using all the above learning materials; (2) Reading aloud; (3) listening to lecture recording; (4) discussions with friends; (5) listening to music; (6) group work.

Students who have numerical and auditory numerical styles as dominant minor learning styles will perform better in every test, task or exam in the following ways: (1) Bring a voice recorder while listening to the lessons especially when repeating past lessons; (2) Accompany the child in learning through question and answer verbally; (3) After they have studied, have them explain the material they have learned as a teacher to his students in class.

Students who have an auditory numerical as a dominant minor learning style will want the following: (1) reading aloud and listening; (2) read stories with various intonations; (3) prefer verbal instruction; (4) if the reading prefers to make a sound because it feels comfortable listening to his own voice.

\section{CONCLUSION AND RECOMMENDATION}

The EFL colllge students who took English as General Course at Universitas Negeri Padang in 2016 have major learning styles which are dominated by Visual Language, Kinesthetic-Tactile, and Visual Numerical. Meanwhile they have minor learning styles which are dominated by Auditory Numerical, Oral Expressiveness, and Social Individu. And and Social Group. The most dominant major learning style is owned by the students in General English Course 2016 at Universitas Negeri Padang is Visual Language. Meanwhile the most dominant learning style not owned by the students is Auditory Numerical.

The finding of this research highlights the importance of recognizing students' varying learning styles. Teachers should be aware of the usefulness of learning styles for effective learning to take place. EFL teachers should consider the students' learning styles and their own teaching styles. Since, this research is focused on EFL students who comes from various study programs, majors, faculty at Universitas Negeri Padang, it is suggested to other researchers to conduct a similar research to EFL students who are majored at English study programs.

This research can be a reference for other research with discussion of gendered based students' learning styles, behaviour based students' learning style, and ability based students' learning style. The result of this research are suggested to be considered by EFL college students at UNP in designing activities and learning activities and for students.

The learning styles framework does not change with subjects, where it actually plays an important role across all the subjects. Therefore, the results here suggest avenues of future research to understand this phenomenon. As a related matter, a study of other learning style variables should also be conducted to bring essential variables to the forefront. Therefore, a further investigation with different data collection methods could contribute to a deeper understanding of what students think about how they learn 
better and why they think so. Besides, the data could be analysed by taking into consideration the variables of gender, majors, and faculties.

\section{References}

[1] Mkonto, Nosisana. "Students' Learning Preferences". Journal of Studies in Education, Vol. 5. (3), 2016 212-235.

[2] Hargrove, L. J. and J. A. Poteet. Assessment in Special Education : The Educational Evaluation. Englewood Cliffs, NJ : Prentice Hall, 1984.

[3] Karabuga, Ferhan. "Match or Mismatch Between Learning Styles of Prep-Class EFL Students and EFL Teachers." Electronic Journal of Foreign Language Teaching, Vol. 12, No. 2. 2015, pp. 276-288.

[4] Gilakjani, Abbas P "A Match or Mismatch Between Learning Styles of the Learners and Teaching Styles of the Teachers." I.J.Modern Education and Computer Science. Vol. 11, 2012, pp. 51-60.

[5] Abidin, Mohamad Jafre Zainol; Rezaee, Abbas Ali; Abdullah, Helan Nor. "Learning Styles and Overall Academic Achievement in a Specific Educational System." International Journal of Humanities and Social Scieces. Vol.1 No.10, 2011, pp. 143-152.

[6] Zhang, L.-F. \& Sternberg, R.J. "A Threefold Model of Intellectual Styles.” Educational Psychology Review, Vol.17, 2005, No. 1.p. 2.

[7] Dörnyei, Z. The Psychology of the Language Learner: Individual Differences in S econd Language Acquisition. London: Lawrence Erlbaum Associates, 2005.

[8] MacKeracher, D. Making Sense of Adult Learning. (2nd ed.). Canada: University of Toronto Press Incorporated, 2004.

[9] Celce-Marcia, M. Teaching English as a Second or Foreign Language. (3rd ed.). New York: Dewey Publishing Services, 2001.

[10] Brown, H. D. Principles of Language Teaching and Learning. (4th ed.). New York: Longman, 2000.

[11] Witkin, H.A. Perception of Body Position and Visual Field in R.J. Drummond. Appraised Procedures for Counselor and Helping Professional. New York: Macmillan Publishing Company, 1949.

[12] Willing, K. Learning Styles in Adult Migrant Education. Adelaide: National Curriculum Resource Center, 1998.

[13] Kolb, D. A. Learning Style Inventory. Boston : McBer and Company, 1976.

[14] Gregorc, A. F. "An Adult's Guide to Style", 1982. in G. Pike and D. Selby. Global Teacher, Global Learner. London : Hodder \& Stoughton, 1992.

[15] Oxford, R.L. 'Language Learning Styles and Strategies'. In M. CelceMurcia (Ed.). Teaching English as a Second or Foreign Language. Boston: Heinle and Heinle, 2001.

[16] Felder, R.M. \& Henriques, E. R.. "Learning and Teaching Styles in Foreign and Second Language Acquisition." Foreign Language Annuals. Vol.28, No.1, 1995, pp. 21-31.

[17] Tulbure, Cristina. "Do Different Learning Styles Require Differentiated Teaching Strategies?" Procedia Social and Behavioral Sciences. Vol. 11, 2011. pp. 155-159.

[18] Sabeh, G., Bahous, R., Bacha, N. N., \& Nabhani, M. "A match or a mismatch between student and teacher learning style preferences." International Journal of English Linguistics. Vol.1, No.1, 2011, pp. $162-172$. 